\title{
DISTRIBUTION AND ENRICHMENT OF HEAVY METALS IN SEDIMENTS AT THE TAPACURÁ RIVER BASIN, NORTHEASTERN BRAZIL
}

\author{
APRILE, F.M. ${ }^{1, *} \&$ BOUVY, M. $^{2}$ \\ ${ }^{1}$ Present address: Istituto per lo Studio degli Ecosistemi, Verbania, Italia. \\ E-mail: aprilefm@hotmail.com \\ ${ }^{2}$ Institut de Recherche pour le Développement, Université du Montpellier II, Montpellier, France. \\ E-mail:bouvy@ird.fr \\ *Correspondence to F. M. Aprile - Rua Doralice Teixeira 48/13 \# 05417-070 São Paulo, Brasil. \\ E-mail address:aprilefm@hotmail.com
}

\begin{abstract}
Aprile, F.M. \& Bouvy, M. 2008. Distribution and enrichment of heavy metals in sediments at the Tapacurá River Basin, Northeastern Brazil. Braz. J. Aquat. Sci. Technol. 12(1):1-8. ISSN 1808-7035. Distribution and enrichment of heavy metals in the sediments at the Tapacurá River basin (Northeastern Brazil) were examined. Sediment samples from eight sites in the basin were collected each three months in the period from April/1997 to January/1999 and between June/2005 and March/2006. Metal levels in sediments varied from 550 to 32,606 Fe, 13.46 to $157.62 \mathrm{Mn}, 0.96$ to $57.32 \mathrm{Cu},<0.01$ to $1.31 \mathrm{~Pb},<0.0005$ to $3.30 \mathrm{Cd}, 4.03$ to $55.16 \mathrm{Zn}, 0.06$ to $6.53 \mathrm{Ni}$ and 0.04 to $5.90 \mathrm{Cr} \mathrm{mg} \mathrm{g}^{-1} \mathrm{dw}$. The concentrations of metals in the industrial and agricultural areas were higher than those in the urban areas. The results demonstrated that terrigenous sediments from the industrial and agricultural areas are dominating factor controlling the spatial variations of heavy metals on the Tapacurá River. Grain size and anthropogenic influences are also major factors modifying the spatial variations of heavy metals. $\mathrm{Pb}$ and $\mathrm{Cd}$ had higher enrichment factors. The maximum potential contamination indices for the basin were 218 to $\mathrm{Pb}$ and 660 to $\mathrm{Cd}$. The correlation analysis showed that the $\mathrm{Fe}$ and $\mathrm{OM}$ varied independently from one another, implies that the concentration of metals in sediments can not be interpreted simply by a change in grain size. The first step to apply a remedial measure is the inspection of the agricultural areas and the use controlled of fertilizers and herbicides. Information of this nature on heavy metals can provide valuable contribution to the program of sanitation at the Companhia Pernambucana de Meio Ambiente - CPRH.

Keywords: trace metal; grain size; Enrichment factor; Index of Contamination; Tropical River
\end{abstract}

\section{INTRODUCTION}

The toxicity of heavy metals on aquatic organisms and its equilibrium is influenced by some limnological factors, such as $\mathrm{pH}$, alkalinity, hardness, salinity, organic matter, total solids, and sedimentation load (Golterman, 2004; Aprile et al., 2005). Human activities can modify the geochemical cycle of heavy metals, resulting in an environmental contamination. Although heavy metals enter rivers and estuaries from many natural sources, one of the most important sources is municipal sewage. The absence of sewage treatment in cities and agricultural runoff in the Tapacurá river basin is responsible for the anthropogenic sources of metallic elements. Researches on the geochemistry of heavy metals in the sediments between the river basin and the surrounding areas are limited. This study examined the temporal and spatial distributions of heavy metals in the Tapacurá River basin sediments, and analyzed the major factors controlling the variations of sedimentary heavy metals. The present paper aims also (1) to establish the heavy metal levels in sediments to evaluate managing strategies of the river basin; (2) to identify sampling sites that had similar or different contamination source zones, and (3) to provide data-base necessary for developing strategies for pollution control and sediment remediation of the basin. Information on the distribution and enrichment of heavy metals at the Tapacurá River can provide valuable contribution to the program of sanitation at the Companhia Pernambucana de Meio Ambiente.

\section{MATERIAL AND METHODS}

\section{Study area}

The Tapacurá River basin (Figure 1) is located in the Zona da Mata region in the state of Pernambuco Northeastern Brazil. It has an average flow of $2.10 \mathrm{~m}^{3} . \mathrm{s}$ ${ }^{1}$ and covers an area of about $360 \mathrm{~km}^{2}$. It receives water flows from four tributaries namely Água Azul River, Itapessirica River, Várzea Grande River and Natuba River which run through the cities of Pombos and Vitória de Santo Antão, and through the agricultural areas (Figure 1). There is not efficiently sewage system in the cities until today, and over $80 \%$ of domestic wastewaters are directly discharged into the tributaries without any treatment. The result is a high concentration of organic sewages in the aquatic resources. Moreover, there are agricultural and industrial areas located in or around 
Tapacurá River basin that contribute a significant amount of untreated and/or minimally treated wastewater to the tributaries. Other pollution source in river basin is the "manipueira," a solid/liquid waste from the improvement of cassava starches that have created great threat to the public health in Pombos city, and enormous impact to the biota due to high toxicity by heavy metals and cyanide acid (Aprile et al., 2004).

\section{Sampling stations}

Overall, 92 sediment samples were collected each three months in the period from April/1997 to January/ 1999 and from June/2005 to March/2006 in the Tapacurá River and tributaries (Figure 1). Given that there was almost no previous data on heavy metal levels in the Tapacurá basin, a priori evaluation of possible pollution sources, anthropic activities, and river morphology was performed to select suitable stations for sample collection. This evaluation indicated that the ecological system of the Tapacurá River is strongly influenced by (I) human activities or domestic sewage, (II) agricultural runoff and (III) industrial plants. Eight sampling stations were selected along the river (Fig. 1 and Table 1).

\section{Sample collection and grain-size analysis}

About $3 \mathrm{~kg}$ sediment samples were obtained using 6" $\times 6$ " $\times 6$ " Ekman Dredge grab sampler, and the superficial $10 \mathrm{~cm}$ sample was retained for analysis. Samples were stored wet in sealed Zip-lock bags at -4 ${ }^{\circ} \mathrm{C}$, and then transported to the laboratory for analysis. The chemical analysis was performed at the Laboratory of Analytical Chemistry of the Companhia Pernambucana de Meio Ambiente and at the Laboratory of Water Chemistry of the Instituto Nacional de Pesquisas da Amazônia. Wet sediment samples were placed in an oven at $105^{\circ} \mathrm{C}$ and heated to a constant weight (Bighman \& Bartels, 1996). The sediment fractions were homogenized and passed through 2.0, 1.0, 0.5, 0.25, $0.125,0.062$, and $0.031 \mathrm{~mm}$ sieves for grain-size analysis (sand, silt, and clay). To remove large pebbles in the sediments they were passed through a 60-mesh sieve and subsequently the sub-samples were passed through 270-mesh $(0.062 \mathrm{~mm})$ sieve before being used in the adsorption trials (for details see 2.4 Sediment analysis).

\section{Sediment analysis}

In brief, analysis of total organic matter content $(\mathrm{OM})$ in the dry sediments was performed using the wet oxidation method with a hydrogen peroxide solution at $100^{\circ} \mathrm{C}$ for four hours (Bighman \& Bartels, 1996). Organic carbon $\left(\mathrm{C}_{\text {org }}\right)$ following carbonate removal with $1 \mathrm{M} \mathrm{HCl}$ was determined on freeze-dried sediment using an elemental analyzer (LECO SC-1440H). The total metals ( $\mathrm{Fe}, \mathrm{Mn}, \mathrm{Cu}, \mathrm{Pb}, \mathrm{Cd}, \mathrm{Zn}, \mathrm{Ni}$ and $\mathrm{Cr}$ ) were digested using mixture $\left(\mathrm{HNO}_{3}+\mathrm{HCl}\right)-\mathrm{HClO}_{4}-\mathrm{HF}$ (Merck 2:1:1) in an open system as described in APHA (1998) and Hyacinthe \& Van Cappellen (2004). Samples (10 g) were treated with $40 \mathrm{ml}$ of the acid mixture, heated at $200^{\circ} \mathrm{C}$ to insipid dryness, re-digested in $5 \mathrm{ml}$ of $\mathrm{HClO}_{4}$ and made up to $50 \mathrm{ml}$ in a volumetric tube (Loring \& Rantala, 1992). Metal concentrations were determined by flame

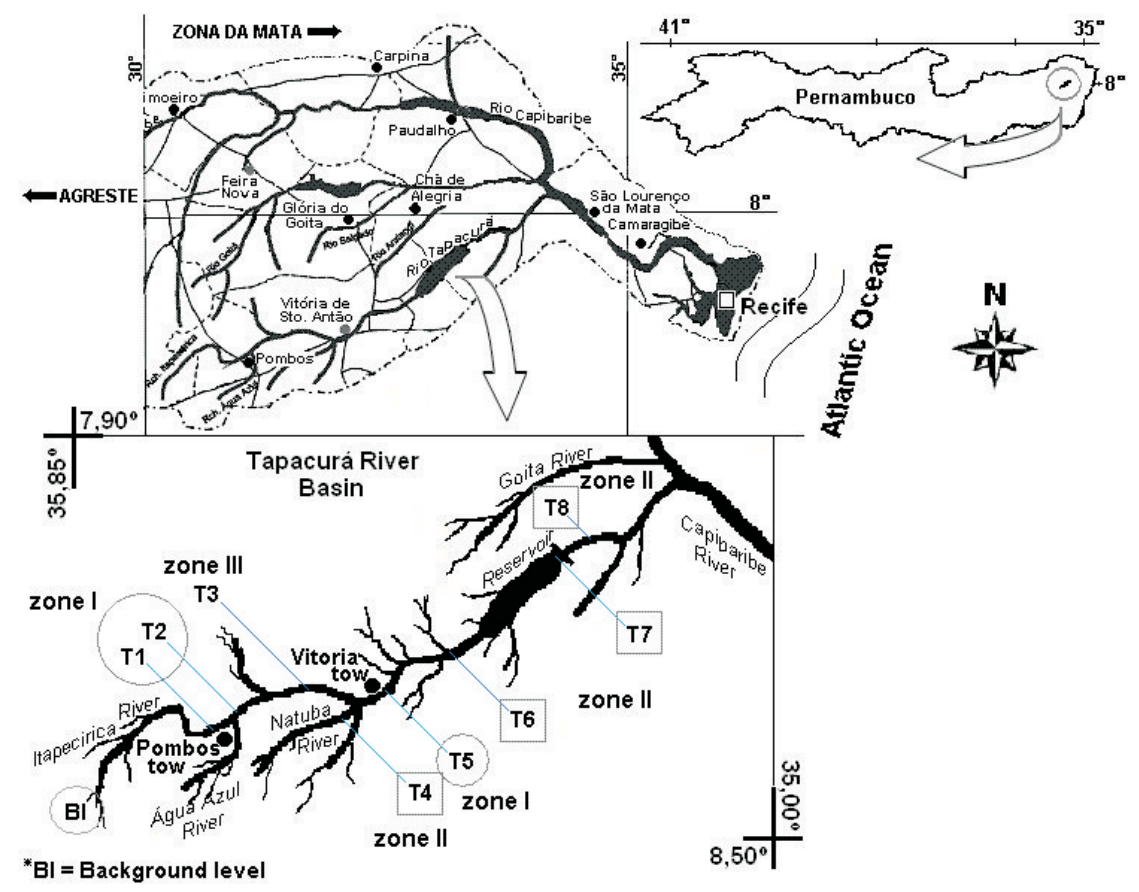

Figure 1 - Location of sampling sites in the Tapacurá River basin, Pernambuco State, Northeastern Brazil. 
Table 1 - Locations of the eight sampling stations along the Tapacurá River basin.

\begin{tabular}{|c|c|c|c|}
\hline Station & Zone & Description & GPS position \\
\hline $\mathrm{T} 1$ & 1 & $\begin{array}{c}\text { Itapecirica River near the Pombos } \\
\text { district }\end{array}$ & $08^{\circ} 07^{\prime} 53^{\prime \prime} \mathrm{S} ; 35^{\circ} 24^{\prime} 58^{\prime \prime} \mathrm{W}$ \\
\hline $\mathrm{T} 2$ & 1 & $\begin{array}{l}\text { Tapacurá River upstream Vitória de } \\
\text { Santo Antão district }\end{array}$ & $08^{\circ} 07^{\prime} 26^{\prime \prime} \mathrm{S} ; 35^{\circ} 22^{\prime} 29^{\prime \prime} \mathrm{W}$ \\
\hline T3 & III & $\begin{array}{l}\text { Tapacurá River at the spirit } \\
\text { company Pitú }\end{array}$ & $08^{\circ} 07^{\prime} 11^{\prime \prime} \mathrm{S} ; 35^{\circ} 19^{\prime} 15^{\prime \prime} \mathrm{W}$ \\
\hline $\mathrm{T} 4$ & II & Natuba River in an agricultural area & $08^{\circ} 10^{\prime} 56^{\prime \prime} \mathrm{S} ; 35^{\circ} 20^{\prime} 22^{\prime \prime} \mathrm{W}$ \\
\hline T5 & I & $\begin{array}{c}\text { Tapacurá River downstream Vitória } \\
\text { de Santo Antão district }\end{array}$ & $08^{\circ} 05^{\prime} 55^{\prime \prime} \mathrm{S} ; 35^{\circ} 15^{\prime} 37^{\prime \prime} \mathrm{W}$ \\
\hline T6 & II & Tapacurá River at the Manaín farm & $08^{\circ} 05^{\prime} 57^{\prime \prime S} ; 35^{\circ} 14^{\prime} 39^{\prime \prime} \mathrm{W}$ \\
\hline $\mathrm{T} 7$ & II & Tapacurá Reservoir & $08^{\circ} 02^{\prime} 12^{\prime \prime} \mathrm{S} ; 35^{\circ} 09^{\prime} 44^{\prime \prime} \mathrm{W}$ \\
\hline T8 & II & $\begin{array}{l}\text { Supply line located about } 300 \\
\text { meters downstream of the dam }\end{array}$ & $08^{\circ} 02^{\prime} 06^{\prime \prime} \mathrm{S} ; 35^{\circ} 09^{\prime} 39^{\prime \prime} \mathrm{W}$ \\
\hline
\end{tabular}

atomic absorption spectrometry using Perkin-Elmer AAS 3300 using air-acetylene flame. Blanks and standard reference materials (SRMs) were included in the analysis to verify the accuracy of the extraction method. Quantification of trace metal concentrations was based upon calibration curves involving standard solutions prepared from a commercial stock solution (trace metals $1 \mathrm{ICM}-411 \mathrm{H}$ in $5 \% \mathrm{HNO}_{3}$, Radian International LLC) and use of standard seawater reference materials (CASS 1-4 and SLEW 1) from the National Research Council of Canada. These calibration curves were determined several times during the period of analysis. The detection limits were $0.05 \mathrm{Fe} ; 0.02 \mathrm{Mn}$; $0.001 \mathrm{Cu} ; 0.01 \mathrm{Ni}, \mathrm{Cr}, \mathrm{Pb}$ and $\mathrm{Cd}$, and $0.003 \mathrm{Zn} \mathrm{mg} \mathrm{g}^{-1}$.

\section{Data analysis}

The extent of metal contamination compared to the background area (see "Ba" Figure 1) was assessed using the enrichment factor (EF, Woitke et al., 2003; Selvaraj et al., 2004). Metal concentrations were normalized to the textural characteristic of sediments with respect to Fe. Iron was selected because it is a major sorbent phase for trace metals, and is a quasiconservative tracer of the natural metal-bearing phases in fluvial and coastal sediments (Schiff \& Weisberg, 1999; Turner \& Millward, 2000). Therefore, EF was defined as:

$$
\mathrm{EF}=\left\{[\text { Metal }]_{\text {sediment }} /[\mathrm{Fe}]_{\text {sediment }}\right\} /\left\{[\text { Metal }]_{\mathrm{Ba}} /[\mathrm{Fe}]_{\mathrm{Ba}}\right\}
$$

An estimate of the amount of metallic elements detectable from sediment analysis was obtained using the potential contamination index $\left(\mathrm{C}_{\mathrm{p}}\right)$ demonstrated by Davaulter \& Rognerud (2001). Therefore, [Metal] $]_{\max }$ is the maximum concentration of a metal in sediment, and $[\text { Metal }]_{\mathrm{Ba}}$ is average value of the same metal in a background level (see "Ba" Figure 1).

$$
\mathrm{C}_{\mathrm{p}}=[\text { Metal }]_{\max } /[\text { Metal }]_{\mathrm{Ba}}
$$

A Pearson Correlation coefficient matrix was determined to heavy metals, OM, $\mathrm{C}_{\text {org }}$ and to the categories of sediment (sand, silt, and clay). The data were analyzed by hierarchical cluster analysis using the complete linkage method as an amalgamation rule.

\section{RESULTS AND DISCUSSION}

Textural characteristics of the sediments are showed according to the classification of Shepard (Shepard \& Moore, 1954). Grain sizes display medium to large variations in the Tapacurá River basin surface sediments. Results showed that course sand (CS 1.0$0.5 \mathrm{~mm}$ ) and medium sand (MS 0.50-0.25 mm) were the dominant fractions of all sediment samples, with range from 12.5 to $29.7 \%$ and 12.7 to $43.2 \%$, respectively. Total means for all study area were $19.7 \pm 4.2 \%$ course sand and $23.9 \pm 8.4 \%$ medium sand. Other results were pebbles with $16.2 \pm 6.6 \%$; very coarse sand (2.0-1.0 $\mathrm{mm}) 15.7 \pm 6.7 \%$; fine sand $(0.250-0.125 \mathrm{~mm}) 11 \pm$ $5.2 \%$; very fine sand $(0.125-0.062 \mathrm{~mm}) 7.4 \pm 5.4 \%$, and silty more clay $(<0.031 \mathrm{~mm}$ ) with $0.15 \pm 0.21 \%$ (Table 2). Stations $T 1, T 3$ and $T 8$ had the highest sand contents $(99.1-99.6 \%)$ and the lowest silt and clay contents (0.01$0.02 \%$ ), while stations T6 and T7, located at the agricultural area (zone II), had the lowest sand content $(93.7-93.8 \%)$ and the highest silt and clay contents $(0.19-0.70 \%$, Table 2 and Figure 2). The more effective contribution in the stations was the fluvial deposition with high values of course sand. This dominance of sand (Figure 2) was related to the high sandy content of natural soils in the area bordered with Agreste region. In general, sediments displayed a normal grain size distribution (symmetrical distribution), with the exception of station T6, located in agricultural area. In that station, sediments displayed a bimodal size distribution. The bimodality indicated that the samples were not homogeneous. In fact, the bimodal appearances of sediment grain sizes indicated that sediments in the station T6 were composed of a mixture between the fine-grained Natuba River sediment and the coarsegrained Tapacurá River sediment.

Among the factors influencing the accumulation of nutrients, particle size played a significant role. Finegrained sediments often show higher concentrations of nutrients due to their greater surface-to-volume ratio and enrichment of OM (Wang et al., 2004). Mean organic matter contents in sediments at the Tapacurá River basin were in the range of $0.4-6.1 \% \mathrm{dw}$ (Figure 2). The results showed that the anthropogenic contribution from discharge of domestic sewage at the Vitória de Santo Antão city was an important source of OM to the station 
Aprile \& Bouvy: Distribution and enrichment of trace metals.

Table 2 - Mean values (\%) of the grain-size analysis at the Tapacurá River basin stations $(n=48)$.

\begin{tabular}{cccccccc}
\hline \hline Station & Pb & VCS & CS & MS & FS & VFS & St+Cy \\
\hline T1 & 14.7 & 15.4 & 29.7 & 32.5 & 5.2 & 2.1 & 0.02 \\
T2 & 10.4 & 6.6 & 14.6 & 43.2 & 15.0 & 7.7 & 0.07 \\
T3 & 30.7 & 19.6 & 19.3 & 18.6 & 6.0 & 5.1 & 0.02 \\
T4 & 8.0 & 16.0 & 19.7 & 24.6 & 21.5 & 8.6 & 0.12 \\
T5 & 23.3 & 25.4 & 23.6 & 15.5 & 4.7 & 3.2 & 0.11 \\
T6 & 8.6 & 4.8 & 12.5 & 26.9 & 17.3 & 23.7 & 0.19 \\
T7 & 15.6 & 13.4 & 18.3 & 21.5 & 15.9 & 9.0 & 0.70 \\
T8 & 22.9 & 28.7 & 24.0 & 12.7 & 6.5 & 4.3 & 0.01 \\
mean & 16.2 & 15.7 & 19.7 & 23.9 & 11.0 & 7.4 & 0.15 \\
SD & 6.6 & 6.7 & 4.2 & 8.4 & 5.2 & 5.4 & 0.21 \\
\hline
\end{tabular}

$\mathrm{Pb}=$ pebbles; $\mathrm{VCS}=$ very course sand; $\mathrm{CS}=$ course sand; $\mathrm{MS}=$ medium sand; $F S=$ fine sand; $V F S=$ very fine sand; $\mathrm{St}+\mathrm{Cy}=$ silte more clay.

T5. High values of organic content at the stations T6 and T7 were due to agricultural activities around Tapacurá reservoir (zone II). The level of OM in the Tapacurá basin was not high in contrasts the others Brazilian rivers. Brigante et al. (2003a) found levels of OM ranged from 0.9 to $48 \%$ in the rivers Peixe, Espraiado, and MogiGuaçu. The organic carbon content ranged from $0.2 \%$ $\mathrm{dw}$ (T1) to $3.3 \% \mathrm{dw}$ (T7) with total average $1.6 \pm 0.9 \%$. Organic carbon concentrations increased reservoir ward, reflecting a corresponding decrease of the sediment grain size. The highest $\mathrm{C}_{\text {org }}$ contents occurred at the stations that had the lowest sand contents and the highest silt and clay contents (Figure 2).

Table 3 presents the mean $\pm S D$, minimum, and maximum concentrations of heavy metal in the surface sediments of all stations studied in the Tapacurá River basin. The concentrations of heavy metals in the sediments were higher at stations T3, T4 and T7 that were identified as hotspots. Heavy metal concentrations in sediments are strongly determined by local geology or anthropogenic influences. The weathering of minerals is one of the major natural sources, while anthropogenic sources include use of fertilizers and herbicides, irrigation, industrial effluent, and leakage from service pipes. In the industrial area (T3) and agricultural activities (stations T4, T6-T8) are likely to be the major contamination sources because of the presence of these actions.

Trace metal concentrations varied substantially in the period of study. The coefficients of variation ranged from $7.77 \%$ for $\mathrm{Mn}$ to $200 \%$ for $\mathrm{Pb}$ both at site T8. Iron levels were highest at station T3 $\left(19.83 \pm 12.57 \times 10^{3} \mu \mathrm{g}\right.$ $\left.\mathrm{g}^{-1}\right)$. High values were also found at station T4 (8.28 \pm $\left.1.31 \times 10^{3} \mu \mathrm{g} \mathrm{g}^{-1}\right)$ and T7 $\left(9.79 \pm 2.19 \times 10^{3} \mu \mathrm{g} \mathrm{g}^{-1}\right)$. Total Fe ranged from 0.55 to $32.61 \times 10^{3} \mu^{g^{-1}}$. The metal Fe is to consider the main factor that determines adsorption capacity, because of the high specific surface of the $\mathrm{Fe}^{3+}$ and $\mathrm{Al}^{3+}$. Moderately high iron levels are also noted

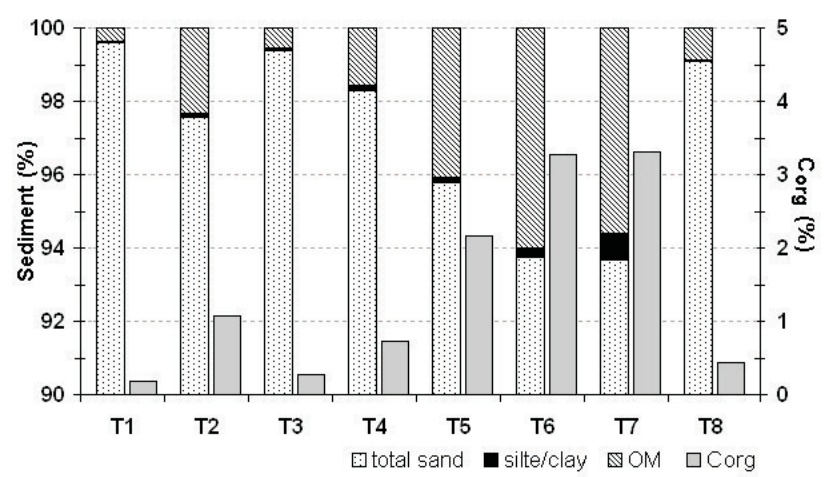

Figure 2 - Characteristics of the sediments at the Tapacurá River basin.

in the sediments that are consistent with high levels of iron in local surface soils (Bighman \& Bartels, 1996). Total $\mathrm{Mn}$ showed higher concentrations at stations T4 $\left(88.57 \pm 44.19 \mu \mathrm{g} \mathrm{g}^{-1}\right)$; T7 $\left(77.92 \pm 9.31{\mu \mathrm{g} \mathrm{g}^{-1}}^{-1}\right)$ and T8 $\left(69.12 \pm 5.37 \mu^{-1} \mathrm{~g}^{-1}\right)$. The lowest levels of Mn were found

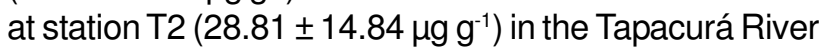
upstream from Vitória de Santo Antão city and at station

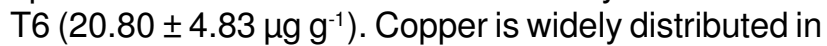
aquatic ecosystems because it is a naturally occurring element. However, $\mathrm{Cu}$ and $\mathrm{Zn}$ concentrations are greatly influenced by anthropogenic sources (IPCS, 1998). Total Cu showed higher concentrations at stations T3 and T4 with $24.87 \pm 20.12 \mu \mathrm{g} \mathrm{g}^{-1}$ and $36.13 \pm 9.97 \mu \mathrm{g} \mathrm{g}{ }^{-1}$, respectively. Total $\mathrm{Zn}$ also showed similar trends with highest level at stations T2-T4 and T7. The results showed an increasing of zinc in the sediments by domestic and industrial wastewaters, and agricultural runoff. The exception was the site T1 that showed lower concentrations for this element. The total lead load does not show any significant spatial or temporal variation when as compared to the others tropical rivers (Eysink et al., 1988; Brigante et al., 2003b; Siqueira, 2003; Jain, 2004; Muniz et al., 2004; Olivares-Rieumont et al., 2005), suggesting that this element was preferentially deposited there by natural occurrence. Total lead ranged from $\leq 0.01$ (detection limit) to $1.31 \mu^{-1} \mathrm{~g}^{-1}$. Cadmium and chromium average levels not exceeded world average levels for surface rock exposed to weathering (Turekian \& Wedepohl, 1961), except to Cd at site T7 $\left(2.22 \pm 1.14 \mu \mathrm{g} \mathrm{g}^{-1}\right)$. Likewise, their concentrations were lower than others tropical rivers (Eysink et al., 1988; Brigante et al., 2003b; Siqueira, 2003; Jain, 2004; Olivares-Rieumont et al., 2005). Total Cr ranged from 0.04 to $5.90 \mu \mathrm{g} \mathrm{g}^{-1}$, and the higher concentration was observed at site T3 $\left(4.25 \pm 1.08 \mu \mathrm{g} \mathrm{g}^{-1}\right)$. Total Ni levels remains more or less constant along the river basin with variation from 0.06 to $6.53 \mu^{g^{-1}}$ (Table 3).

The enrichment factor (EF) values (Table 4) were interpreted with support of the classification of Taylor (1964) to abundance of heavy metals in the continental 
Braz. J. Aquat. Sci. Technol., 2008, 12(1):1-8.

Table 3 - Concentrations (mean \pm SD) and range of trace metals ( $\mathrm{mg} \mathrm{g}^{-1}$ dry weight) in the surface sediments of the Tapacurá River basin.

\begin{tabular}{ccccccccc}
\hline Site & $\mathbf{F e} / 10^{3}$ & $\mathbf{M n}$ & $\mathbf{C u}$ & $\mathbf{P b}$ & $\mathbf{C d}$ & $\mathbf{Z n}$ & $\mathbf{N i}$ & $\mathbf{C r}$ \\
\hline $\mathrm{T} 1$ & $4.15 \pm 0.55$ & $32.53 \pm 8.24$ & $5.63 \pm 0.68$ & $0.08 \pm 0.08$ & - & $7.82 \pm 1.85$ & $0.39 \pm 0.03$ & $0.81 \pm 0.26$ \\
$(\mathrm{n}=10)$ & $3.38-4.83$ & $22.52-40.18$ & $4.94-6.45$ & $<0.01-0.17$ & $<0.01$ & $5.70-10.38$ & $0.33-0.41$ & $0.54-1.20$ \\
$\mathrm{~T} 2$ & $5.51 \pm 4.33$ & $28.81 \pm 14.84$ & $7.31 \pm 6.57$ & $0.16 \pm 0.18$ & - & $20.58 \pm 5.60$ & $0.53 \pm 0.42$ & $0.45 \pm 0.55$ \\
$(\mathrm{n}=11)$ & $1.30-9.59$ & $13.46-42.80$ & $1.05-13.52$ & $<0.01-0.36$ & $<0.01$ & $14.30-28.18$ & $0.12-0.93$ & $0.04-1.33$ \\
$\mathrm{~T} 3$ & $19.83 \pm 12.57$ & $51.58 \pm 35$ & $24.87 \pm 20.12$ & $0.35 \pm 0.35$ & $0.22 \pm 0.03$ & $36.28 \pm 14.82$ & $3.93 \pm 2.30$ & $4.25 \pm 1.08$ \\
$(\mathrm{n}=12)$ & $6.78-32.61$ & $19.14-92.18$ & $11.82-57.32$ & $0.03-0.74$ & $0.19-0.25$ & $20.80-55.16$ & $1.63-6.53$ & $3.16-5.90$ \\
$\mathrm{~T} 4$ & $8.28 \pm 1.31$ & $88.57 \pm 44.19$ & $36.13 \pm 9.97$ & $0.67 \pm 0.56$ & $0.23 \pm 0.04$ & $25.64 \pm 4.74$ & $0.80 \pm 0.52$ & $3.32 \pm 0.52$ \\
$(\mathrm{n}=12)$ & $6.87-10.07$ & $48.42-157.6$ & $23.91-45.78$ & $0.01-1.31$ & $0.18-0.27$ & $21.42-33.09$ & $0.27-1.47$ & $2.66-3.78$ \\
$\mathrm{~T} 5$ & $1.25 \pm 0.48$ & $61.24 \pm 23.36$ & $3.65 \pm 1.80$ & $0.01 \pm 0.01$ & - & $11.46 \pm 1.64$ & $0.40 \pm 0.18$ & $0.55 \pm 0.53$ \\
$(\mathrm{n}=12)$ & $0.55-1.79$ & $40.03-90.57$ & $0.96-5.45$ & $<0.01-0.02$ & $<0.01$ & $8.95-12.99$ & $0.14-0.58$ & $0.12-1.38$ \\
$\mathrm{~T} 6$ & $4.44 \pm 2.52$ & $20.80 \pm 4.83$ & $6.96 \pm 5.06$ & $0.09 \pm 0.09$ & - & $14.17 \pm 10.59$ & $0.18 \pm 0.11$ & $1.26 \pm 0.44$ \\
$(\mathrm{n}=11)$ & $1.86-7.21$ & $15.46-25.30$ & $3.20-15.05$ & $<0.01-0.19$ & $<0.01$ & $4.03-24.18$ & $0.06-0.32$ & $0.62-1.77$ \\
$\mathrm{~T} 7$ & $9.79 \pm 2.19$ & $77.92 \pm 9.31$ & $8.24 \pm 1.46$ & $0.20 \pm 0.22$ & $2.22 \pm 1.14$ & $23.72 \pm 4.01$ & $0.66 \pm 0.27$ & $0.99 \pm 0.49$ \\
$(\mathrm{n}=12)$ & $7.94-12.86$ & $63.77-85.86$ & $6.82-10.24$ & $<0.01-0.45$ & $1.11-3.30$ & $19.98-27.74$ & $0.33-1.00$ & $0.48-1.45$ \\
$\mathrm{~T} 8$ & $6.51 \pm 1.94$ & $69.12 \pm 5.37$ & $7.61 \pm 3.89$ & $0.01 \pm 0.02$ & - & $12.01 \pm 5.07$ & $1.29 \pm 0.33$ & $2.05 \pm 0.53$ \\
$(\mathrm{n}=12)$ & $5.05-9.57$ & $60.73-74.08$ & $3.58-11.28$ & $<0.01-0.04$ & $<0.01$ & $7.47-19.87$ & $0.83-1.70$ & $1.51-2.86$ \\
\hline
\end{tabular}

crust, and based in the values of a background area near to the basin (see "Ba" Figure 1). The EF of some heavy metals as chromium (eight stations $E F<1$ ), zinc and nickel (seven stations EF $<1$ ) indicated there is not enrichment by these metals in the sediments of the basin. This result means that these metals in the sediments of the river basin are close to background levels. High EF values as 20.5 for $\mathrm{Pb}$ in T4 and 68.4 for Cd in T7 both in zone II (Fig. 1) can mean a high amount of metallic discharge from agricultural runoff. Enrichment factor is a good tool to differentiate the metal source between anthropogenic and naturally occurring (Woitke et al., 2003; Selvaraj et al., 2004; Adamo et al., 2005).

Potential contamination indices $\left(\mathrm{C}_{\mathrm{p}}\right.$, Table 4$)$ showed that $54.7 \%$ of the samples were higher than three indicated severe or very severe contamination by heavy metals in the sediments. The metals that showed the most extensive contamination were $\mathrm{Fe}$ (ranged from $1.2-21.4$ ) and $\mathrm{Pb}$ (ranged from 3.3 - 218.3). The highest contamination index, however, was determined to the $\mathrm{Cd}\left(\mathrm{C}_{\mathrm{p}}=660\right)$ in the site T7. The heavy metals that showed the narrowest contamination were $\mathrm{Cr}$ and $\mathrm{Ni}$. The sampling sites T3, T4, and T7 showed the highest degree of anthropogenic impact estimated based in the $\mathrm{C}_{\mathrm{p}}$ to the sediments of the Tapacurá basin. According to National Recommended Water Quality Criteria Correction by U.S. Office of Water Drinking Water and Health (US-EPA, 1999), and reports on the establishing of safe values to heavy metals in soil, water and human health (WHO, 1996; CETESB, 2001), in the Tapacurá
River basin was not observed high levels of contamination by heavy metals in the sediments.

Pearson Correlation was determined to the limnological parameters with base on eight sampling sites $(\mathrm{n}=92)$, and significance at $p<0.050$. Fe correlation was high for $\mathrm{Mn}$ and $\mathrm{Cu}$ (both $\left.\mathrm{r}^{2}=0.78\right)$ and $\mathrm{Cr}\left(\mathrm{r}^{2}=0.73\right)$, and stronger for $\mathrm{Zn}\left(\mathrm{r}^{2}=0.88\right)$ and $\mathrm{Ni}\left(\mathrm{r}^{2}=0.92\right)$. Sand concentrations displayed stronger negative correlations with OM $\left(r^{2}=-0.99\right)$ and $C_{\text {org }}\left(r^{2}=-0.99\right)$. The concentrations of $\mathrm{Cu}$ and $\mathrm{Cr}$ in sediments of the Tapacurá River were also strongly correlated $\left(r^{2}=0.81\right)$, suggesting similar associations between that metals in the lake bottom. Sediment grain size is one of the main controlling factors for the distribution of heavy metals in an aquatic ecosystem, normally presented strong negative correlation with metals. The distribution of grain size and organic matter content are two critical factors that influencing the metal distribution in sediments (Aloupi \& Angelidis, 2001; Liaghati et al., 2003). Course sand particles with diameter $\geq 0.5 \mathrm{~mm}$ consist of geological minerals (e.g. quartz, feldspars), and the heavy metals in these fractions are principally in the crystalline solid form and are environmentally immobile. The fine particles as silt, clay, and colloidal materials yet are generally surface-active and contain $\mathrm{OM}$ and $\mathrm{Fe} / \mathrm{Mn}$ oxide in association, which can contribute to the deposition of metals. In this research, the correlation of Pearson showed that the concentrations of $\mathrm{Fe} / \mathrm{Mn}$ and $\mathrm{OM}$ in the sediment varied independently from one another. Other important fact observed the correlation 
Aprile \& Bouvy: Distribution and enrichment of trace metals.

Table 4 - Degree of anthropogenic impact estimated based in the enrichment factor $(E F)^{*}$ and potential contamination index $\left(C_{p}\right)^{* \star}$ to the sediments of the Tapacurá River basin.

\begin{tabular}{|c|c|c|c|c|c|c|c|c|c|c|c|c|c|c|c|c|}
\hline & \multicolumn{2}{|c|}{$\mathrm{Fe}$} & \multicolumn{2}{|c|}{$\mathbf{M n}$} & \multicolumn{2}{|c|}{$\mathrm{Cu}$} & \multicolumn{2}{|c|}{$\mathrm{Pb}$} & \multicolumn{2}{|c|}{$\mathrm{Cd}$} & \multicolumn{2}{|c|}{$\mathrm{Zn}$} & \multicolumn{2}{|c|}{$\mathrm{Ni}$} & \multicolumn{2}{|c|}{$\mathrm{Cr}$} \\
\hline & $\mathrm{EF}$ & $\mathrm{C}_{\mathrm{p}}$ & $\mathrm{EF}$ & $\mathrm{C}_{\mathrm{p}}$ & $\mathrm{EF}$ & $\mathrm{C}_{\mathrm{p}}$ & EF & $C_{p}$ & $\mathrm{EF}$ & $C_{p}$ & $\mathrm{EF}$ & $C_{p}$ & $\mathrm{EF}$ & $C_{p}$ & $\mathrm{EF}$ & $C_{p}$ \\
\hline T1 & 1.0 & 3.2 & 0.5 & 1.6 & 0.5 & 1.4 & 5.0 & 28.3 & 0.4 & 1.0 & 0.4 & 1.4 & 0.4 & 1.0 & 0.3 & 1.1 \\
\hline T2 & 1.0 & 6.3 & 0.3 & 1.7 & 0.4 & 3.0 & 7.5 & 60.0 & 0.3 & 1.0 & 0.8 & 3.8 & 0.4 & 2.3 & 0.1 & 1.2 \\
\hline T3 & 1.0 & 21.4 & 0.2 & 3.6 & 0.4 & 12.7 & 4.5 & 123.3 & 3.4 & 50.0 & 0.4 & 7.4 & 0.8 & 16.3 & 0.3 & 5.4 \\
\hline T4 & 1.0 & 6.6 & 0.6 & 6.2 & 1.5 & 10.2 & 20.5 & 218.3 & 8.3 & 54.0 & 0.6 & 4.4 & 0.4 & 3.7 & 0.6 & 3.4 \\
\hline T5 & 1.0 & 1.2 & 2.9 & 3.6 & 1.0 & 1.2 & 2.0 & 3.3 & 1.2 & 1.0 & 1.9 & 1.7 & 1.2 & 1.5 & 0.6 & 1.3 \\
\hline T6 & 1.0 & 4.7 & 0.3 & 1.0 & 0.5 & 3.3 & 5.0 & 31.7 & 0.3 & 1.0 & 0.6 & 3.2 & 0.2 & 0.8 & 0.4 & 1.6 \\
\hline T7 & 1.0 & 8.4 & 0.5 & 3.4 & 0.3 & 2.3 & 5.3 & 75.0 & 68.4 & 660.0 & 0.5 & 3.7 & 0.3 & 2.5 & 0.1 & 1.3 \\
\hline T8 & 1.0 & 6.3 & 0.6 & 2.9 & 0.4 & 2.5 & 0.4 & 6.7 & 0.2 & 1.0 & 0.4 & 2.6 & 0.8 & 4.3 & 0.4 & 2.6 \\
\hline
\end{tabular}

* EF $<1$ no enrichment; $E F{ }^{31} 1-<3$ minor enrichment; $E F{ }^{33}-<5$ moderate enrichment; $E F=35-<10$ moderately - severe enrichment; $E F{ }^{3} 10-<25$ severe enrichment; $E F{ }^{325}-<50$ very severe enrichment and $E F{ }^{3} 50$ extremely severe enrichment (Taylor, 1964). ${ }^{* *} \mathrm{C}_{\mathrm{p}}>3$ (bold) P severe contamination.

analysis was weaker between the metallic elements and the sedimentary fractions. This implies that the concentration of heavy metals in sediments cannot be interpreted simply by a change in grain size can be involved other physical-chemical processes.

Table 5 shows the average metal concentrations reported in sediments from different tropical regions of the world in comparison with this work. Trace metal concentrations showed a conservative behavior in sediments of the Tapacurá River. The exceptions were Fe with SD range from 0.48 to $12.57 \times 10^{3} \mathrm{\mu g} \mathrm{g}^{-1}$ and $\mathrm{Mn}$ (moderate to high SD - range from 4.83 to $44.19 \mu \mathrm{g} \mathrm{g}^{-1}$, see Table 3). A general increase in the sediment metallic fraction from river to site T7 was observed, due to the decrease of the water flux at the reservoir.

Cluster analysis (Fig. 3) was engaged to quantitatively identify areas with similar characteristics of metallic concentration. Heavy metal concentrations in sediments can very greatly depending on the source natural or anthropogenic such as, sewage, lixiviation including agricultural runoff, and erosion processes. A major cluster can be seen with zones I (domestic sewage) and II (agricultural activities). The station T3 was isolated owing to its typical pollution sources (zone III = industrial activities). A strong cluster includes stations T4, T6, T7 and T8 was observed which represents moderately to severe contamination by heavy metals in the sediments. Probably, one of the most important natural factors controlling the spatial variations of the heavy metals in the sediments included limnological processes, such as sorption and adsorption. Heavy metals in water-sediment interface can combine with different organic groups, such as amino acids, peptides, proteins, and carbohydrates. The association occurs between the metallic ion and the functional group (e.g. carboxyl acid or amine) of the organic compound. The oxygen level in the water can influence in the velocity of this association. Its concentration can regulate metabolic rates of benthonic organisms and decomposition processes.

Results indicate that heavy metals are been accumulated in the sediments of the basin, and they are greatly influenced by anthropogenic sources that include use of fertilizers and herbicides, municipal sewage, and industrial effluents. Chemical adsorption between the metals, grain size, and organic matter contributed largely in the metal immobilization process. The colloidal complex OM-metal can be stable in the sediment. In the Tapacurá River basin, there is not a program to remediate the contaminated water or sediments by heavy metals. We believe that the first step to apply a remedial measure and management strategies is the inspection of the agricultural areas surrounding of the basin, and the use controlled of fertilizers and herbicides. Heavy metal reduction from sources such as municipal sewage and industrial effluents is a more practicable approach.

\section{CONCLUSIONS}

The heavy metals showed a heterogeneous horizontal distribution. In the Tapacurá River basin was not observed high levels of contamination by heavy metals in sediments according to criterions at the US-EPA (1999), WHO (1996) and CETESB (2001). However, data analyses by $\mathrm{EF}$ and $\mathrm{C}_{\mathrm{p}}$ indicated contamination by $\mathrm{Pb}$ and $\mathrm{Cd}$ in the river basin. The metallic levels in the industrial and agricultural areas were higher than those in the urban areas, and consequently hotspots of 
Braz. J. Aquat. Sci. Technol., 2008, 12(1):1-8.

Table 5 - Concentration of heavy metals in sediments of different rivers of the world $\left(\mathrm{mg} \mathrm{g}^{-1}\right)$.

\begin{tabular}{|c|c|c|c|c|c|c|c|c|c|}
\hline Region & $\mathbf{F e}$ & Mn & $\mathrm{Cu}$ & $\mathbf{P b}$ & Cd & $\mathrm{Zn}$ & $\mathbf{N i}$ & $\mathrm{Cr}$ & Source \\
\hline World average & 46700 & 850 & 45 & 20 & 0.3 & 95 & 68 & 90 & Turekian and Wedepohl (1961) \\
\hline Almendares river, Cuba & - & - & 158 & 93 & 2.5 & 262 & - & 138 & $\begin{array}{r}\text { Olivares-Rieumont et al. } \\
\text { (2005) }\end{array}$ \\
\hline Yamuna river, India & - & - & 22 & 58 & 10.1 & 62 & - & - & Jain (2004) \\
\hline Montevideo harbor, Uruguay & - & - & $58-135$ & $44-128$ & $<1-1.6$ & $174-491$ & - & $79-253$ & Muniz et al. (2004) \\
\hline Ribeira river, SE Brazil & - & - & $7-60$ & $4-4000$ & $0.2-5.5$ & $15-4090$ & - & - & Eysink et al. (1988) \\
\hline Mogi-Guaçu river, SE, Brazil & 36400 & $51-332$ & $2.8-49$ & $5.1-109$ & $0.01-5$ & $12-103$ & $19.3-44$ & $5.4-135$ & Brigante et al. (2003b) \\
\hline Amazon River mouth, Brazil & 38300 & 600 & 37.5 & 83 & - & 110 & 26.7 & 65 & Siqueira (2003) \\
\hline Pará River mouth, NE Brazil & 44500 & 700 & 37.0 & 95.5 & - & 122 & 32.5 & 75 & Siqueira (2003) \\
\hline Tapacurá river, NE Brazil & 7470 & 53.8 & 12.5 & 0.2 & 0.3 & 18.9 & 1.1 & 1.7 & Present study \\
\hline
\end{tabular}

contamination were identified. The results indicated the potential pathways of heavy metals via the transport of sediment from the agricultural areas to the reservoir.

Statistical analysis indicated a conservative behavior by the trace metals in the Tapacurá River, exceptions to $\mathrm{Fe}$ and $\mathrm{Mn}$. Results indicate also that heavy metals are been accumulated in the sediments of the basin, and they are deeply influenced by anthropogenic sources such as fertilizers and herbicides, municipal sewage, and industrial effluents. The accumulation of metal contaminants in sediments can pose serious environmental problems to the surrounding areas. Results can help develop management strategies for pollution control and sediment remediation mainly in the agricultural areas surrounding of the basin with severe contamination.

\section{ACKNOWLEDGEMENTS}

The authors extend their thanks to colleagues at the Companhia Pernambucana do Meio Ambiente $(\mathrm{CPRH})$ and at the Institut de Recherche pour le Développement (IRD) in Pernambuco for valuable help with the sampling and chemical analyses, to CNPq for the important financially support (Project number \# 301746/96.6), and constructive comments from anonymous reviewers significantly improved the manuscript.

\section{REFERENCES}

Adamo, P.; Arienzo, M.; Imperato, M.; Naimo, D.; Nardi, G. \& Stanzione, D. 2005. Distribution and partition of heavy metals in surface and sub-surface sediments of Naples city port. Chemosphere. 61:800-809.

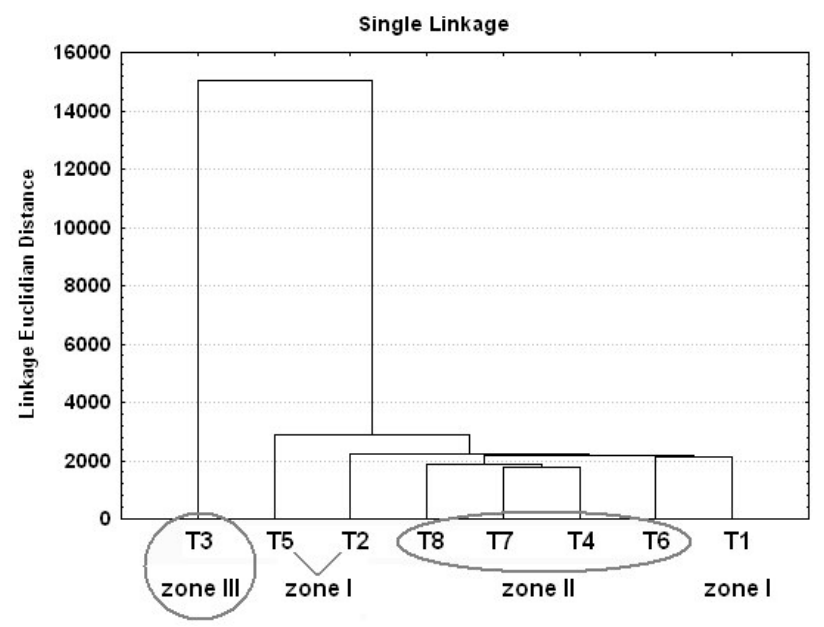

Figure 3 - Dendrogram indicating relatedness of sample sites with heavy metal concentration among the eight sampling stations.

Aloupi, M. \& Angelidis, M.O. 2001. Geochemistry of natural and anthropogenic metals in the coastal sediments of the island of Lesvos, Aegean Sea. Environ. Pollut. 113:211-219.

APHA (American Public Health Association), 1998. American Water Works Association and Water Environment Federation. Standard Methods for the Examination of Water and Wastewater, 20th ed. American Public Health Association, Washington, USA.

Aprile, F.M.; Parente, A.H. \& Bouvy, M., 2004. Industrial residues analysis of the processing of Cassava Flour in the Rio Tapacurá Basin (Pernambuco State/ Brazil). Bioikos. 18(1):63-69. (in Portuguese).

Aprile, F.M.; Siqueira, G.W. \& Parente, A.H. 2005. Occurrence and potentially toxic of heavy metals in aquatic ecosystems and their effects on organisms health. Quim. Tecnol. 1/2:40-47. 
Bighman, J. \& Bartels, J. 1996. Chemical Methods. In: Sparks, D.L. (ed.) Methods of Soil Analysis, Part 3. Soil Sci. Soc. of Am., Book Series 5, Madison, WI.

Brigante, J.; Espíndola, E.L.G.; Povinelli, J.; Silva, M.R.C.; de Nogueira, A.M. \& Antônio Filho, V. 2003a. Physical and chemical characterization of sediment at the Mogi-Guaçu River. In: Brigante, J. \& Espíndola, E.L.G. (eds.) River limnology. A study at the Mogi-Guaçu River. Rima ed., São Paulo. 7784pp. (in Portuguese).

Brigante, J.; Silva, M.R.C.; Queiroz, L.A. \& Coppi, E. 2003b. Metals quantification in water and sediment of the Mogi-Guaçu River In: Brigante, J. \& Espíndola, E.L.G. (eds.) River limnology. A study at the MogiGuaçu River. Rima ed., São Paulo. 85-120pp. (in Portuguese).

CETESB. 2001. Report of establishing of values to soil and groundwater of the São Paulo State. Relatórios Ambientais, 246p (in Portuguese).

Davaulter, V. \& Rognerud, S. 2001. Heavy metal pollution in sediments of the Pasvik River drainage. Chemosphere. 42:9-18.

Eysink, G.G.J.; de Pádua, H.B.; Piva-Bertoletti, S.A.E.; Martins, M.C. \& Pereira, D.N. 1988. Heavy metals in the Vale do Ribeira and in Iguape-Cananéia. CETESB, Ambiente. 2(1):6-13 (in Portuguese).

Golterman, H.L. 2004. The Chemistry of Phosphate and Nitrogen Compounds in Sediment. Kluwer Academic Publishers, Dordrecht/ Boston/London, 246p.

Hyacinthe, C. \& Van Cappellen, P. 2004. An authigenic iron phosphate phase in estuarine sediments: Composition, formation and chemical reactivity. Mar Chem. 91:227-251.

IPCS (International Programme on Chemical Safety). 1998. Environmental heath criteria 200. Copper. World Health Organization, Geneva, 360p.

Jain, C.K. 2004. Metal fractionation study on bed sediments of River Yamuna, India. Water Res. 38(3):569-578.

Liaghati, T.; Preda, M. \& Cox, M. 2003. Heavy metal distribution and controlling factors within coastal plain sediments, Bells Creek catchment, southeast Queensland, Australia. Environ. Inter. 29:935-948.

Loring, D.H. \& Rantala, R.T.T. 1992. Manual for the geochemical analyses of marine sediments and suspended particulate matter. Earth-Sci. Rev. 32:235-283.

Muniz, P.; Danula, E.; Yannicelli, B.; Garcia-Alonso, J.; Medina, G. \& Bicego, M.C. 2004. Assessment of contamination by heavy metals and petroleum hydrocarbons in sediments of Montevideo Harbour (Uruguay). Environ. Inter. 29:1019-1028.
Olivares-Rieumont, S.; de La Rosa, D.; Lima, L.; Graham, D.W.; Alessandro, K.D.; Borroto, J.; Martínez, F. \& Sánchez, J. 2005. Assessment of heavy metal levels in Almendares River sediments Havana City, Cuba. Water Res. 39(16):3945-3953.

Schiff, K.C. \& Weisberg, S.B. 1999. Iron as a reference element for determining trace metal enrichment in southern California coastal shelf sediments. Mar. Environ. Res. 48:161-176.

Selvaraj, K.; Ram Mohan, V. \& Szefer, P. 2004. Evaluation of metal contamination in coastal sediments of the Bay of Bengal, India: geochemical and statistical approaches. Mar. Pollut. Bull. 49:174-185.

Shepard, F.P. \& Moore, D.G. 1954. Sedimentary environments differentiated by coarse fraction studies: Bull. Am. Assoc. Petrol. Geologists. 38:1792-1802.

Siqueira, G.W. 2003. Study of heavy metals levels and other elements in surface sediments at the Santos Estuarine System and Shelf Coastal of the Amazon. PhD thesis, São Paulo University, Instituto Oceanográfico, Brazil, 386p (in Portuguese).

Taylor, S.R. 1964. Abundance of chemical elements in the continental crust: a new table. Geochim. Cosmochim. Acta. 28:1273-1285.

Turekian, K.K. \& Wedepohl, K.H. 1961. Distribution of the element in some major units of the earth's crust. Bull. Geol. Soc. Am. 72:175-192.

Turner, A. \& Millward, G.E. 2000. Particle dynamics and trace metal reactivity in estuarine plumes. Estuar. Coast. Shelf Sci. 50:761-774.

US-EPA (United States Environmental Protection Agency). 1999. National Recommended Water Quality Criteria Correction Office of Water. EPA 822Z-99-001, U.S. EPA, 25p.

Wang, G.P.; Liu, J.S. \& Tang, J. 2004. The long-term nutrient accumulation with respect to anthropogenic impacts in the sediments from two freshwater marshes (Xianghai Wetlands, Northeast China). Water Res. 38(20):4462-4474.

WHO (World Health Organization). 1996. Trace elements in human nutrition and health. Chapters 5 - 7. Geneva, WHO, pp.72-143.

Woitke, P.; Wellmitz, J.; Helm, D.; Kube, P.; Lepom, P. \& Litheraty, P. 2003. Analysis and assessment of heavy metal pollution in suspended solids and sediments of the river Danube. Chemosphere. 51:633-642. 